\title{
Teaching NeuroImages: Godtfredsen syndrome due to retroclival subdural hematoma
}

S. Deepak Amalnath, MD

Neurology ${ }^{\circledR}$ 2018;91:e999-e1000. doi:10.1212/WNL.0000000000006125

Figure 1 Left 6th and 12th nerve palsies

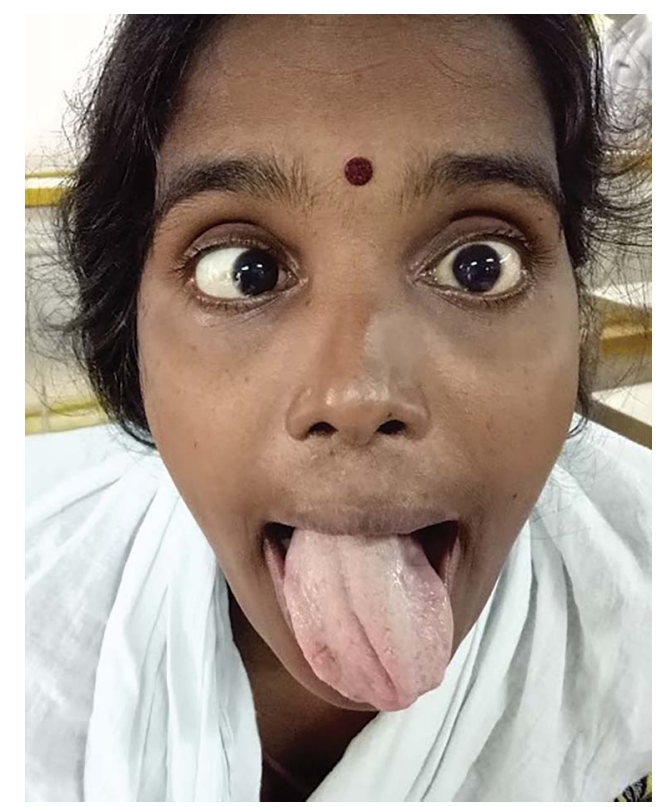

On looking to the left, there is impaired abduction of the left eye (left 6th nerve palsy) and deviation of the tongue to left side (left 12th nerve palsy).

A 30-year-old woman presented with sudden onset headache of 2 days duration. She was on warfarin $7.5 \mathrm{mg}$ once a day owing to prosthetic heart valves (international normalized ratio of 3.5).

The patient had isolated bilateral 6th and left 12th cranial nerve palsies (figure 1) with sparing of the 5th nerve.

Imaging showed a retroclival subdural hematoma extending from the posterior clinoid processes to the body of $\mathrm{C} 2$ vertebra, with compression of the brainstem (figure 2).

The unique combination of 6 th and 12th nerve palsies helps to localize the lesion to the clivus ${ }^{1}$ (Godtfredsen ${ }^{2}$ syndrome or clival syndrome).

Of note, Godtfredsen ${ }^{2}$ had attributed the 6th nerve palsy to invasion of the cavernous sinus by nasopharyngeal carcinoma and the 12 th nerve palsy to retropharyngeal lymph node metastasis.

\section{Correspondence}

Dr. Amalnath

drdeepakmddm@

yahoo.co.in

\section{MORE ONLINE}

\section{$\rightarrow$ Teaching slides}

links.lww.com/WNL/

A651 
Figure 2 Retroclival subdural hematoma

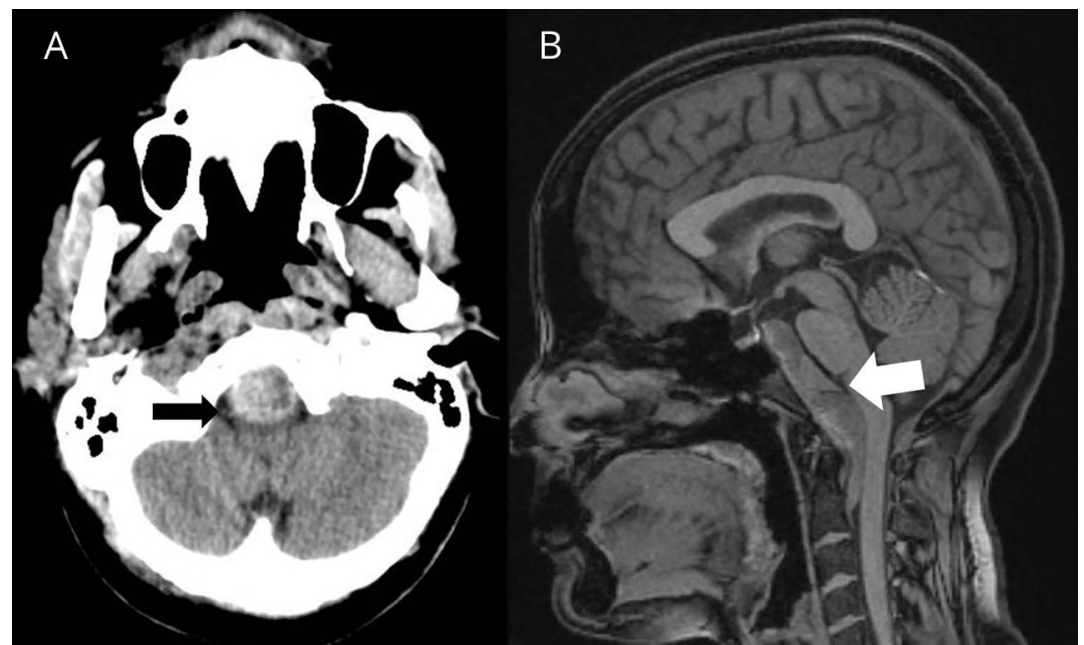

$\mathrm{CT}$ brain (A) shows retroclival hematoma (black arrow) and MRI (B) shows the hematoma in the subdural space (white arrow) extending to the body of C2 vertebra.

\section{Author contributions}

S. Deepak. Amalnath did the study concept and design, acquisition of data analysis and interpretation of data.

\section{Study funding}

No targeted funding reported.

\section{Disclosure}

S.D. Amalnath reports no disclosures relevant to the manuscript. Go to Neurology.org/N for full disclosures.

\section{References}

1. Keane JR. Combined VIth and XIIth cranial nerve palsies: a clival syndrome. Neurology 2000;54:1540-1541.

2. Godtfredsen E. Ophthalmo-neurological symptoms in connection with malignant nasopharyngeal tumours. Br J Ophthalmol 1947;31:78-100. 


\section{Neurology}

\section{Teaching NeuroImages: Godtfredsen syndrome due to retroclival subdural hematoma}

S. Deepak Amalnath

Neurology 2018;91;e999-e1000

DOI 10.1212/WNL.0000000000006125

This information is current as of September 3, 2018

Updated Information \&

Services

References

Subspecialty Collections

Permissions \& Licensing

Reprints including high resolution figures, can be found at: http://n.neurology.org/content/91/10/e999.full

This article cites 2 articles, 2 of which you can access for free at: http://n.neurology.org/content/91/10/e999.full\#ref-list-1

This article, along with others on similar topics, appears in the following collection(s):

All Cerebrovascular disease/Stroke

http://n.neurology.org/cgi/collection/all_cerebrovascular_disease_strok e

Clinical neurology examination

http://n.neurology.org/cgi/collection/clinical_neurology_examination

Information about reproducing this article in parts (figures,tables) or in its entirety can be found online at:

http://www.neurology.org/about/about_the_journal\#permissions

Information about ordering reprints can be found online:

http://n.neurology.org/subscribers/advertise

Neurology ${ }^{\circledR}$ is the official journal of the American Academy of Neurology. Published continuously since 1951, it is now a weekly with 48 issues per year. Copyright @ 2018 American Academy of Neurology. All rights reserved. Print ISSN: 0028-3878. Online ISSN: 1526-632X.

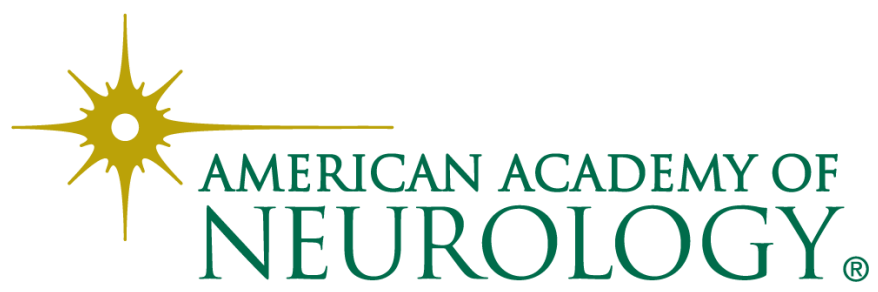

